\title{
Establishment, production and regeneration of subterranean clovers in the Mackenzie Basin, New Zealand
}

\author{
S.T. OLYKAN ${ }^{1}$, R.J. LUCAS ${ }^{1}$, C.S. TEIXEIRA ${ }^{1}$, R.A. SUBTIL ${ }^{2}$ and D.J. MOOT ${ }^{1}$ \\ ${ }^{1}$ Dryland Pastures Research, Field Research Centre, Faculty of Agriculture \& Life Sciences, \\ PO Box 85084, Lincoln University, Lincoln 7647, New Zealand \\ ${ }^{2}$ Omarama Station, 59 Omarama-Lindis Pass Rd, Omarama 9448, New Zealand
} Sonya.Olykan@lincoln.ac.nz

\begin{abstract}
The 'Red Flats' on Omarama Station in the Mackenzie Basin, has a winter cold, summer dry environment and soils with low plant available water $(<60 \mathrm{~mm}$ in the top $1 \mathrm{~m})$, and low $\mathrm{pH}\left(\mathrm{H}_{2} \mathrm{O}\right)$ (5.2) and high aluminium (8 $\mathrm{mg} / \mathrm{kg}$ ) below $75 \mathrm{~mm}$. The site received $3 \mathrm{t}$ of lime, $300 \mathrm{~kg}$ sulphur-super, boron (B), molybdenum (Mo) and herbicides to eliminate hieracium (Hieracium pilosella). Twelve cultivars of subterranean clover (Trifolium subterraneaum), 'Bolta' balansa clover ( $T$. michelianum), and perennial 'Rossi' red clover ( $T$. pratense), were direct-drilled in February 2016. Over the next 3 years their frost tolerance, productivity and persistence were compared with the resident haresfoot clover ( $T$. arvense). Balansa and the subterranean clovers all survived the 2016 and 2017 winters. The subterranean clovers maximum yield was $4.3 \mathrm{t} \mathrm{DM} /$ ha after successful germination in February 2016 when sufficient rain extended the spring growing season into November. Subterranean clover cultivars from subspecies subterraneum yielded well in 2016, averaging $3.3 \mathrm{t} \mathrm{DM} / \mathrm{ha}$, as did the brachycalycinum 'Antas' with $3 \mathrm{t} \mathrm{DM} /$ ha. During the short season of 2017, the subterraneum ssp. cultivars 'Denmark' and 'Karridale' established the highest ground covers and 'Antas' the lowest. In 2018, 'Antas' had the lowest emergence rate and autumn yield. 'Karridale' had the highest re-establishment rate and the yanninicum 'Trikkala' the highest autumn yield (1.3 t DM/ha). Cultivars with low hardseededness ratings were the most successful at re-establishment in autumn 2017. Balansa clover was also persistent. In the favourable 2016 growing season the late-flowering resident haresfoot clover grew into early summer and yielded 3.7 $\mathrm{t} \mathrm{DM} /$ ha. Red clover yielded $1 \mathrm{t} \mathrm{DM} /$ ha in 2016, but did not persist. Results suggest that medium-late flowering softer seeded subterranean clover cultivars and 'Bolta' balansa clover, are suitable for this environment.
\end{abstract}

Keywords: cold tolerance, dryland, legume

\section{Introduction}

Historically, pasture legume research in the Mackenzie Basin has focussed on introducing improved perennial species (Allan \& Keoghan 1994). However, the dominance of annual resident haresfoot (Trifolium arvense) clover on undeveloped drier sites suggests annual legumes, such as subterranean (T. subterraneum) and balansa clovers (T. michelianum), may be used to improve pastures in lower rainfall areas.

Subterranean clover seed has been imported from Australia for pastoral use since the 1920s (Saxby 1956). The performance of a number of subterranean clover strains (cultivars), at Palmerston North, was reported by Levy \& Gorman (1937), but they noted that only seeds of 'Mt Barker' and 'Tallarook' were available in New Zealand at that time. These two cultivars have since become 'resident' in New Zealand hill-country (Suckling et al. 1983) and adapted to environmental conditions and grazing management practices (Macfarlane \& Sheath 1984), particularly in the North Island.

Research in New Zealand has aimed to select "superior" ecotypes adapted to New Zealand conditions (Dodd et al. 1995; Widdup \& Pennell 2000), but these have not been commercialised. New Zealand seed companies, and farmers, are reliant on the importation of available subterranean clover seed from Australia, where the current breeding priorities are for traits to increase persistence and productivity for the benefit of the Australian livestock and grain industries (Nichols et al. 2013).

Subterranean clover cultivars differ in flowering date, length of growing season, hardseededness and the proportion of burr burial (Nichols et al. 2013). The cultivars belong to one of three subspecies (ssp.): subterraneum (adapted to well-drained soils, soil $\mathrm{pH}\left(\mathrm{H}_{2} \mathrm{O}\right) 5.0$ to 7.5 ), yanninicum (adapted to poorly drained or high water-holding capacity soils, soil $\mathrm{pH}\left(\mathrm{H}_{2} \mathrm{O}\right) 6.0$ to $>7.5$ ), or brachycalycinum (adapted to well-drained cracking or stony soils, $\mathrm{pH}\left(\mathrm{H}_{2} \mathrm{O}\right) 6.0$ to >7.5) (Ghamkhar et al. 2015).

Previous research, under controlled conditions, found that 'Tallarook' could withstand temperatures as low as -6 to $-7^{\circ} \mathrm{C}$ (Caradus 1995). At Wairakei, a frostprone site, Macfarlane et al. (1990) found large cultivar differences in frost scores, based on the percentage of leaves showing necrosis. 'Trikkala' was moderately 
affected (66\% of leaves damaged) and 'Woogenellup' one of the least affected (25\%), but frosting did not cause plant death. Dear \& Loveland (1984) found no clear evidence that heavy frosts (as low as $-12^{\circ} \mathrm{C}$ ) during subterranean clover flowering reduced seed production in the cool tableland environment of Canberra, Australia (620 m a.s.1.). McGuire (1985) reported that subterranean clover grown in the United States had survived winter temperatures as low as $-20^{\circ} \mathrm{C}$.

In a legume pot trial, Moir et al. (2016) identified an optimal soil $\mathrm{pH}\left(\mathrm{H}_{2} \mathrm{O}\right)$ range of 5.6 to 6.0 for ' $\mathrm{Mt}$ Barker' subterranean clover and a soil exchangeable aluminium (Al) concentration threshold of $4 \mathrm{mg} / \mathrm{kg}$. 'Bolta' balansa clover had a narrow optimal $\mathrm{pH}\left(\mathrm{H}_{2} \mathrm{O}\right)$ range of 5.7 to 5.9 and soil $\mathrm{Al}$ threshold of $3 \mathrm{mg} / \mathrm{kg}$.

Little is known about the potential performance of the newer Australian-bred subterranean clover cultivars in cold climatic conditions common in inland dryland hill and high country (Moir \& Moot 2014). Thus, the Mackenzie Basin was used to test whether 12 subterranean clover cultivars, including newly available untested cultivars, could establish, grow and persist in this continental climate with surface applied lime to modify the low soil $\mathrm{pH}$ and high $\mathrm{Al}$ status.

\section{Methodology and analysis}

An experiment to test the agronomic value of subterranean clover was established in February 2016 on the infertile 'Red Flats' of Omarama Station in the Mackenzie Basin, New Zealand (GPS coordinates are $-44.503479,169.902127,477 \mathrm{~m}$ a.s.1.). The flats were formed from alluvial schist and greywacke gravel deposits (Brash \& Beecroft 1987). The resulting Mackenzie soils (Pallic Orthic Brown) are shallow (depth 20-45 cm) and well drained which results in low plant available water (30-60 $\mathrm{mm}$ in the top $1 \mathrm{~m}$ ) (S-MAP
2017). The site was a depleted short tussock (Festuca novae-zelandiae) grassland dominated by sheep's sorrel (Rumex acetosella) and hieracium (Hieracium pilosella). In 2012 there was an unsuccessful attempt to establish lupins (Lupinus polyphyllus) and cocksfoot (Dactylis glomerata). Some cocksfoot survived, but the site reverted to a mixture of hieracium, sheep's sorrel, and resident haresfoot clover.

\section{Site preparation}

Site preparation included the surface application of 3 t/ha of agricultural lime $(99 \%<2.4 \mathrm{~mm}, 44 \%<0.15$ $\mathrm{mm}$ particle size) in August 2015. This was followed by herbicides to eliminate hieracium while minimising the residual risk to the sown legumes $(3.5 \mathrm{~L} / \mathrm{ha}$ of $2,4-\mathrm{D}$ Ester on 11th September 2015; $8 \mathrm{~L} /$ ha glyphosate on 18th September 2015, and $5 \mathrm{~L} /$ ha glyphosate on 10th February 2016). There was also an application of 3.5 $\mathrm{L} / \mathrm{ha}$ MoBstar (containing $100 \mathrm{~g} / \mathrm{L}$ elemental boron (B) and $2.5 \mathrm{~g} / \mathrm{L}$ elemental molybdenum (Mo), applied 18th September 2015), and the addition of $340 \mathrm{~kg} / \mathrm{ha}$ of Sulphur Super 30 (phosphorus (P) 7, sulphur (S) 30, calcium (Ca) 16, applied 18th February 2016).

\section{Soil chemical data}

In the $0-75 \mathrm{~mm}$ soil depth, the addition of lime increased $\mathrm{pH}\left(\mathrm{H}_{2} \mathrm{O}\right)$ and $\mathrm{Ca}$ after 2.7 years (by April 2018, Table 1) and may have reduced exchangeable magnesium $(\mathrm{Mg})$. The sulphur-super was applied at sowing (18th February 2016) and 6 weeks later in March 2016 the Olsen P was $24 \mathrm{mg} / \mathrm{L}$, but declined to $12 \mathrm{mg} / \mathrm{L}$ after 2 years (April 2018) (Table 1). The levels of $\mathrm{SO}_{4}-\mathrm{S}$ and organic-S are low considering a range of 10 to $12 \mathrm{mg} / \mathrm{kg}$ for both of these $\mathrm{S}$ forms is optimum for pasture production (Edmeades et al. 2005). In April 2018 the amount of $\mathrm{SO}_{4}-\mathrm{S}$ was higher in the 75-150

Table 1

Soil nutrient levels in samples taken from 0-75 and 75-150 mm in May 2015 (before lime and fertiliser additions) from the same paddock as used by Hendrie et al. (2018), and in March 2016 and April 2018 from the legume experimental area at Omarama Station. MAF Quick Test units are shown in brackets for the cations. NA $=$ not analysed.

\begin{tabular}{|c|c|c|c|c|c|c|}
\hline \multirow[b]{2}{*}{ Soil depth (mm) } & \multicolumn{2}{|c|}{ May 2015} & \multicolumn{2}{|c|}{ March 2016} & \multicolumn{2}{|c|}{ April 2018} \\
\hline & $0-75$ & $75-150$ & $0-75$ & $75-150$ & $0-75$ & $75-150$ \\
\hline $\mathrm{pH}\left(\mathrm{H}_{2} \mathrm{O}\right)$ & 5.7 & 5.3 & 5.7 & 5.2 & 6.0 & 5.3 \\
\hline Olsen P (mg/L) & 16 & NA & 24 & 9 & 12 & 9 \\
\hline Potassium (me/100 g) & $0.46(9)$ & NA & $0.54(13)$ & $0.16(4)$ & $0.31(6)$ & $0.20(4)$ \\
\hline Calcium (me/100 g) & $2.8(4)$ & NA & $4.9(7)$ & $1.0(1)$ & $5.1(6)$ & $1.2(2)$ \\
\hline Magnesium (me/100 g) & $0.60(14)$ & NA & $0.44(11)$ & $0.21(5)$ & $0.43(9)$ & $0.23(5)$ \\
\hline CEC (me/100 g) & 10 & & 10 & 9 & 12 & 10 \\
\hline $\mathrm{SO}_{4}$-sulphur $(\mathrm{mg} / \mathrm{kg})$ & 7 & NA & NA & NA & 5 & 12 \\
\hline Organic sulphur (mg/kg) & 4 & NA & NA & NA & 4 & 3 \\
\hline Aluminium $_{(\mathrm{CaCl} 2)}(\mathrm{mg} / \mathrm{kg})$ & 1.5 & 8.0 & 0.6 & 8.3 & 0.9 & 7.3 \\
\hline
\end{tabular}


mm depth (Table 1). The amount of Al below $75 \mathrm{~mm}$ is greater than the $4 \mathrm{mg} / \mathrm{kg}$ threshold Moir et al. (2016) identified for subterranean clover, and the top 0-75 mm depth of soil contains more nutrients (Table 1) which is consistent with the shallow rooting depth of 8 to 11 $\mathrm{cm}$ observed for excavated subterranean clover plants (unpublished data).

\section{Experimental details}

Three replicates of 12 subterranean clover cultivars (Table 2) were sown at $20 \mathrm{~kg}$ bare seed/ha on 18th February 2016, using a Flexiseeder $\AA$, in 8 x 2.1 m plots with a randomised complete block design. Two other legume species, 'Bolta' balansa clover and 'Rossi' red clover (T. pratense), were also sown at $10 \mathrm{~kg} / \mathrm{ha}$. One of three unplanted plots/replicate was used to monitor the resident haresfoot clover giving a total of 45 plots.

On 23rd February 2016, 1.25 L/ha of Lorsban (active ingredient chlorpyrifos) was applied as a precaution against clover root weevil (Sitona lepidus) attack.

\section{Climate data}

Hourly rainfall was measured on-site (K.M. Pollock pers. comm.) and the 'Tara Hills Aws' climate station (Agent No. 5212, $2.9 \mathrm{~km}$ from the site) provided additional temperature, potential evapotranspiration (PET) and long-term climate data (CliFlo 2018). Annual rainfall at Omarama is about $500 \mathrm{~mm}$, however, the loss to PET measured at Tara Hills, is about $1000 \mathrm{~mm} /$ year with summer months averaging $150+\mathrm{mm}$. At Tara Hills in 2016 and 2017, the soil moisture deficit was $<10 \mathrm{~mm}$ for short periods from mid-July to August. In 2016 and 2017, there were 6 months during autumn, winter and spring when total monthly rainfalls at Omarama were $<20 \mathrm{~mm}$ (Figure 1). Annual rainfall at Omarama was $493 \mathrm{~mm}$ in 2016 and $474 \mathrm{~mm}$ in 2017.

At Omarama the length of the subterranean clover growing season was governed by rainfall patterns. Subterranean clover germination only occurred after a rainfall event of at least $20 \mathrm{~mm}$. "False strikes", also known as "false breaks" (Taylor et al. 1991), result from summer or early autumn rainfall followed by dry conditions (Sheath \& Macfarlane 1990), and the germinated seed does not receive sufficient moisture to survive (Teixeira et al. 2018). In 2016 a successful germination and establishment happened immediately after sowing in mid-February $(36 \mathrm{~mm}$ rainfall over 2 days) and the subterranean clover growing season lasted about 9 months, ending in November (Figure 1). In 2017 a successful subterranean clover germination and establishment phase was delayed until mid-April (40 $\mathrm{mm}$ rainfall over 2 days) and growth finished in early October resulting in a potential growing season of less than 6 months. In 2018, there was 67 $\mathrm{mm}$ of rainfall at the start of February (Figure 1) that stimulated subterranean clover germination and those plants survived and established.

The lowest grass minimum temperature recorded

Table 2 Agronomic data for the subterranean clover cultivars sown at Omarama Station in February 2016.

\begin{tabular}{|c|c|c|c|c|c|c|c|}
\hline $\begin{array}{l}\text { Subterranean } \\
\text { clover cultivar }\end{array}$ & $\begin{array}{c}\text { Sub- } \\
\text { species }^{1}\end{array}$ & Year $^{2}$ & $\begin{array}{l}\text { Hardseededness } \\
\text { rating }^{3}\end{array}$ & $\begin{array}{c}\text { Flowering } \\
\text { time }^{4}\end{array}$ & $\begin{array}{l}\text { Growing } \\
\text { season }^{5} \\
\text { (months) }\end{array}$ & $\begin{array}{c}\text { Burr } \\
\text { burial }^{6}\end{array}$ & $\begin{array}{l}\text { TSW } \\
(g)^{7}\end{array}$ \\
\hline 'Antas' & B & 1999 & 3 & Late & 7.5 & 1 & 11.1 \\
\hline 'Campeda' & $\mathrm{S}$ & 1999 & 5 & Mid & 6.0 & 6 & 7.6 \\
\hline 'Denmark' & $\mathrm{S}$ & 1992 & 2 & Late & 7.5 & 5 & 6.9 \\
\hline 'Karridale' & $\mathrm{S}$ & 1985 & 2 & Late & 7.5 & 6 & 6.8 \\
\hline 'Leura' & $\mathrm{S}$ & 1992 & 2 & Very late & 8.0 & 5 & 7.9 \\
\hline 'Monti' & $Y$ & 2013 & 2 & Early & 5.5 & 6 & 9.8 \\
\hline 'Napier C’8 & $Y$ & 2001 & 5 & Late & 7.5 & 6 & 12.2 \\
\hline 'Rosabrook' & $\mathrm{S}$ & 2009 & 5 & Late & 7.5 & 6 & 8.4 \\
\hline 'Trikkala' & $\mathrm{Y}$ & 1975 & 2 & Early & 5.5 & 6 & 8.4 \\
\hline 'Woogenellup' & $\mathrm{S}$ & 1959 & 1 & Mid & 7.0 & 3 & 10.1 \\
\hline
\end{tabular}

1 Subspecies: $\mathrm{B}=$ brachycalycinum, $\mathrm{S}=$ subterraneum, $\mathrm{Y}=$ yanninicum.

2 Year seed first sold or date cultivar registered in Australia (Nichols et al. 2013).

3 Hardseededness rating: $1=$ least hard, $10=$ most hard, (Nichols et al. 2013).

${ }^{4}$ Flowering time for New Zealand conditions (D.J. Moot \& Dryland Pastures Research Team 2016). Early is from mid-Sept, late is from mid-Oct.

${ }^{5}$ Growing season is the minimum length for reliable seed production (Nichols et al. 2013).

${ }^{6}$ Burr burial: 1 = low to $9=$ high (Nichols et al. 2013).

7 TSW: Thousand Seed Weight of bare seed.

${ }^{8}$ Sown as coated seed. 


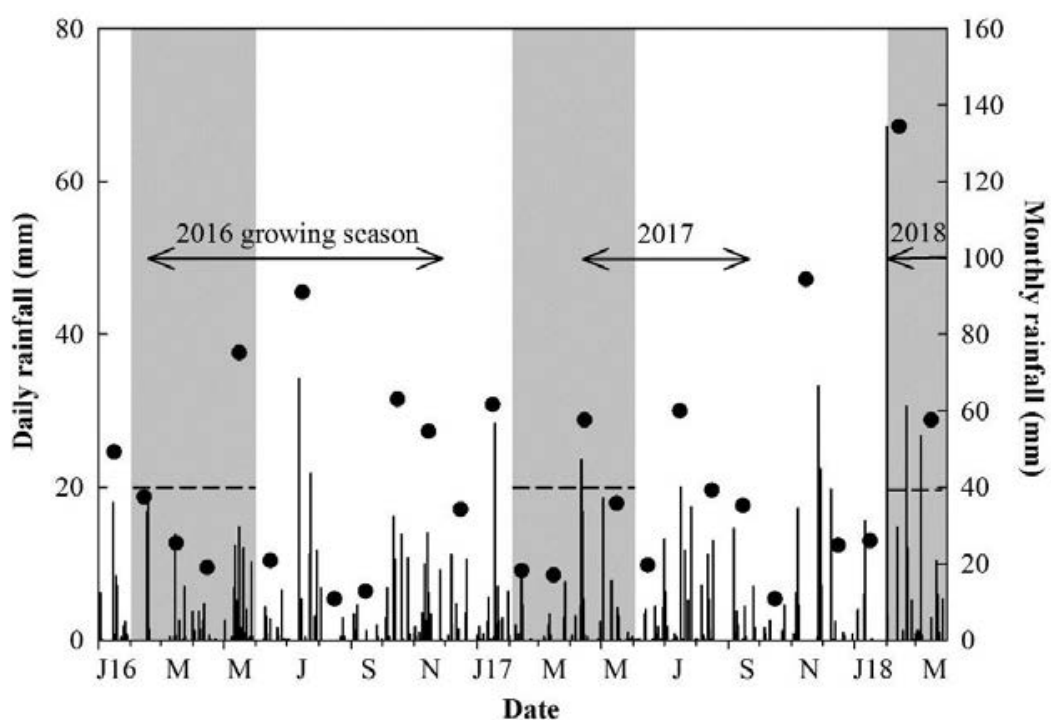

Figure 1 Daily ( | ) and monthly $(\bullet)$ rainfall at the Omarama Station experimental site from January 2016 to March 2018. Grey shaded areas, 1st February to 31st May, are the main germination period for subterranean clover, which occurred after a $20+\mathrm{mm}$ rainfall event (---). Estimated length of the subterranean clover growing seasons represented by the solid line $(\mathrm{n})$.

at Tara Hills in 2016 was $-10.4^{\circ} \mathrm{C}$ on 2 nd July 2016 . During June, July and August the grass minimum temperature went below $-7^{\circ} \mathrm{C}$ on 2,5 and 3 days respectively. No frost heave, when young seedlings are ejected from the soil, was observed. The winter of 2017 had grass minimum temperatures below $-7^{\circ} \mathrm{C}$ on 16 days: 6,8 and 2 days, respectively, for the months of June, July and August. The lowest grass minimum temperature was $9.7^{\circ} \mathrm{C}$ (5th August 2017).

\section{Year 1 (2016)}

On 31st March 2016 (6 weeks after sowing, small rosette growth stage) the established legume seedlings were counted in a $50 \mathrm{~cm}$ length of row in each plot. Bulk soil samples, based on 10 cores from 0-75 and 75$150 \mathrm{~mm}$ depths, were taken from replicates 1 and 3 for chemical analysis (see Table 1). On 7th June 2016 (16 weeks, rosette stage) a cold sensitivity assessment was carried out, after a number of heavy frosts of $\leq-5^{\circ} \mathrm{C}$. The intensity of leaf redness (redness score) was assessed visually on a scale from one $(1=$ green leaves, no reddening) to five $(5=$ dark red colour). The percentage of plants/plot exhibiting foliar redness was estimated (0 to $100 \%$ ). The cold sensitivity score was calculated by multiplying the redness score by the percentage of plants affected. Above-ground legume biomass was sampled from a $20 \mathrm{~cm}$ length of row in each plot. From 25th July 2016 the area was grazed for a week with mixed-age ewes to a residual of $\sim 200 \mathrm{~kg} \mathrm{DM} / \mathrm{ha}$. On 3rd November 2016 (37 weeks, plants flowering) herbage biomass was sampled (using motorised shears to $10 \mathrm{~mm}$ stubble height) from a $0.2 \mathrm{~m}^{2}$ quadrat of "good" subterranean clover area in each plot (i.e. not obviously affected by surface stoniness) to indicate the productive potential. The subsamples were sorted into sown legume, haresfoot clover, broadleaf weeds, weed grasses and dead material. A third herbage biomass was sampled on $1 \mathrm{st}$ December 2016 (41 weeks, plants setting seed and senescing) and the plots scored for senescence.

Year 2 (2017)

On 23rd May 2017 (6 weeks after germination, small rosette) the emergence of the subterranean clover seedlings, in a $0.1 \times 0.1 \mathrm{~m}$ quadrat representing the best $\mathrm{patch} / \mathrm{plot}$, was visually scored from zero (no emergence) to five (excellent emergence), and the scores converted to estimated seedling population numbers using the methods developed by Teixeira et al. (2017). On 20th October 2017 (27 weeks, plants flowering) the herbage was only 10 to $20 \mathrm{~mm}$ in height and was deemed too short to harvest. Instead, the percent groundcover occupied by the herbage components (sown clover, broadleaf weeds, weed grasses, and haresfoot clover) and bare ground were visually estimated. The site was not grazed during 2017.

\section{Year 3 (2018)}

On 23rd February 2018 (3 weeks after germination, 2 trifoliate leaf stage) seedling emergence was scored as described for 23rd May 2017. On 18th April 2018 (11 weeks, rosette stage) herbage biomass was sampled, as for 3rd November 2016. Bulk soil samples, based on five cores/plot from $0-75$ and $75-150 \mathrm{~mm}$ depths, were taken from each replicate. A subsample from each replicate was bulked for chemical analysis (see Table $1)$.

\section{Data analysis}

Subterranean clover cultivar data were analysed with Genstat (18th Ed.) using one-way ANOVA (complete randomised blocks) with orthogonal contrasts of subterranean clover ssp., hardseededness, old (registered before 1999) versus new cultivars, flowering time, and length of growing season. Tukey's honestly 


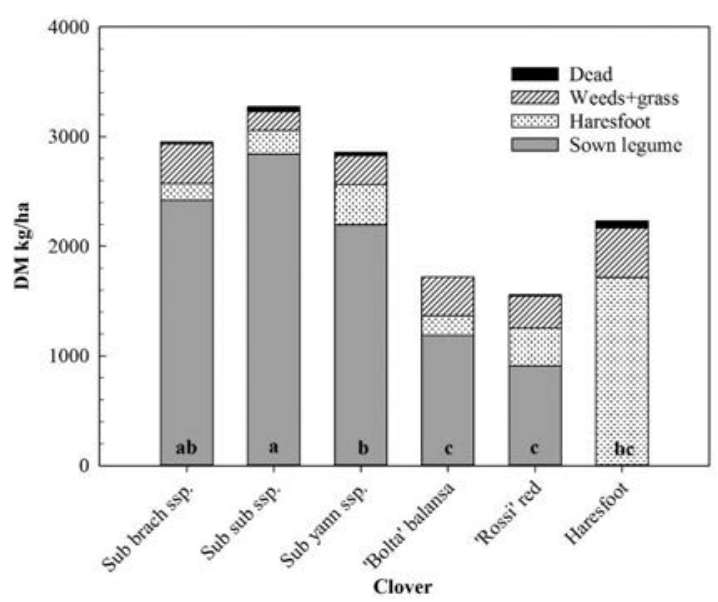

Figure 2 Dry matter (DM) production and botanical composition of sown clovers and the resident haresfoot clover on 3rd November 2016, after sowing in February 2016 at Omarama Station. Sown legume and haresfoot means with the same letter are not different (Fisher's LSD, $\mathrm{a}=0.05$ ).

significant difference (HSD) test was used for multiple comparisons of cultivar means. For groundcover analysis, some components, e.g. weeds, grass, and haresfoot clover, were combined. The skewed cold sensitivity score data were square root-transformed and the back-transformed data presented. For the 18th April 2018 dry matter yield, the best two replicates were analysed. Simple linear regression was used to correlate variables. Analysis of an unbalanced design using Genstat regression was used for comparing the subterranean clover subspecies, balansa, red and haresfoot clovers. Fisher's least significant differences $\left(\mathrm{LSD}_{5 \%}\right)$ was used for means separation.

\section{Results}

\section{6 results - establishment and growth}

Six weeks after sowing (31st March 2016), on average, $82 \%$ of the viable bare subterranean clover seed had emerged and plant populations averaged 180 plants/ $\mathrm{m}^{2}$. There was no cultivar effect $(\mathrm{P}=0.40)$ on the initial establishment because commercial bare subterranean clover seed is scarified and this nullifies the potential effect of hardseededness. Balansa clover established 260 plants $/ \mathrm{m}^{2}$ (38\% emergence) and red clover 200 plants $/ \mathrm{m}^{2}$ (47\% emergence).

In early winter (7th June 2016) the subterranean clover cultivars differed $(\mathrm{P}<0.001)$ in their cold sensitivity scores, which ranged from 0 to 2.4. Orthogonal contrasts showed that the yanninicum ssp. had a higher $(\mathrm{P}<0.001)$ score of 1.9 compared with 0.4 for the subterraneum ssp. and 0.0 for the brachycalycinum, 'Antas'. However, there was no correlation $(\mathrm{P}=0.128)$ between cold sensitivity and dry matter production to November.

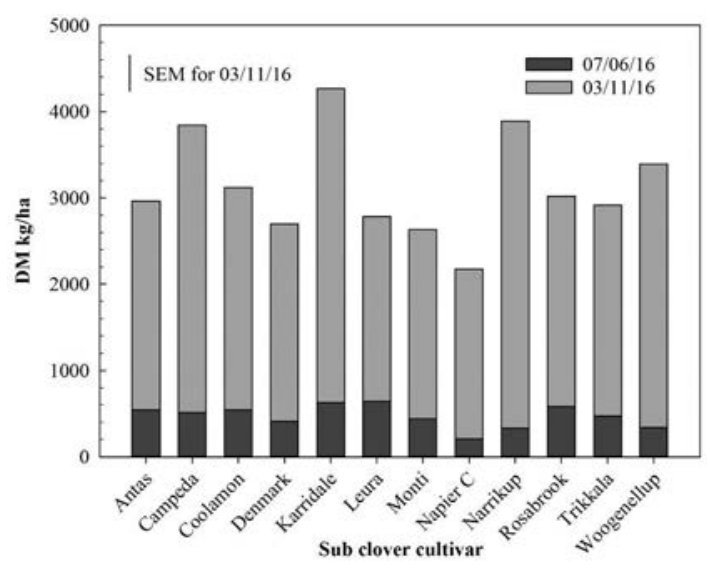

Figure 3 Accumulated dry matter (DM) yield of subterranean clover cultivars at Omarama Station from harvests on 7th June 2016 and 3rd November 2016.

Dry matter sampling in late spring (3rd november 2016) highlighted the success $(\mathrm{P}<0.001)$ of subterranean clover compared with the other clovers (Figure 2). The average subterraneum ssp. cultivar yield was $2840 \mathrm{~kg}$ $\mathrm{DM} / \mathrm{ha}$ and higher than the yanninicum ssp. average of $2200 \mathrm{~kg} \mathrm{DM} / \mathrm{ha}(\mathrm{P}<0.05)$. The brachycalycinum 'Antas' produced $2420 \mathrm{~kg} \mathrm{DM} / \mathrm{ha}$. Balansa and red clover produced 1190 and $910 \mathrm{~kg} \mathrm{DM} / \mathrm{ha}$, respectively. The resident haresfoot produced $1710 \mathrm{~kg} \mathrm{DM} / \mathrm{ha}$.

For these subterranean clover monocultures, cultivar yield at the first harvest on 7th June 2016 were not different $(\mathrm{P}=0.807)$ and averaged $470 \mathrm{~kg}$ $\mathrm{DM} /$ ha (Figure 3). By 3rd November 2016, the yield was lower $(\mathrm{P}=0.025)$ in the yanninicum ssp. than the subterraneum $\mathrm{ssp}$. (Figure 2 ). The accumulated yields for 2016 were not different $(\mathrm{P}=0.225)$ among individual cultivars. However, the yield of the yanninicum ssp. $(2580 \mathrm{~kg} \mathrm{DM} / \mathrm{ha})$ was lower $(\mathrm{P}=0.029)$ than the subterraneum ssp. (3330 kg DM/ha). 'Bolta' balansa accumulated $1320 \mathrm{~kg} \mathrm{DM} / \mathrm{ha}$ to $3 \mathrm{rd}$ November 2016, 'Rossi' red clover $1020 \mathrm{~kg} \mathrm{DM} / \mathrm{ha}$ and haresfoot 1830 $\mathrm{kg} \mathrm{DM} / \mathrm{ha}$. On average, botanical composition on $3 \mathrm{rd}$ november 2016 was $82 \%$ subterranean clover, $7 \%$ haresfoot, $10 \%$ broadleaf weeds plus grass and $1 \%$ dead material.

At the third harvest (1st December 2016) there was no cultivar effect $(\mathrm{P}=0.857)$ on subterranean clover yield. Visual observations indicated that subterranean clover in $77 \%$ of the plots was senescing and the average yield of $2200 \mathrm{~kg} \mathrm{DM} / \mathrm{ha}$, was lower than the $3 \mathrm{rd}$ November 2016 harvest of $2670 \mathrm{~kg} \mathrm{DM} / \mathrm{ha}$. Botanical composition was $74 \%$ subterranean clover, $11 \%$ haresfoot, $2 \%$ broadleaf weeds and grass and $13 \%$ dead material. The resident haresfoot continued to grow into the summer and had an accumulated yield of $3700 \mathrm{~kg} \mathrm{DM} / \mathrm{ha}$ by $1 \mathrm{st}$ December 2016. 


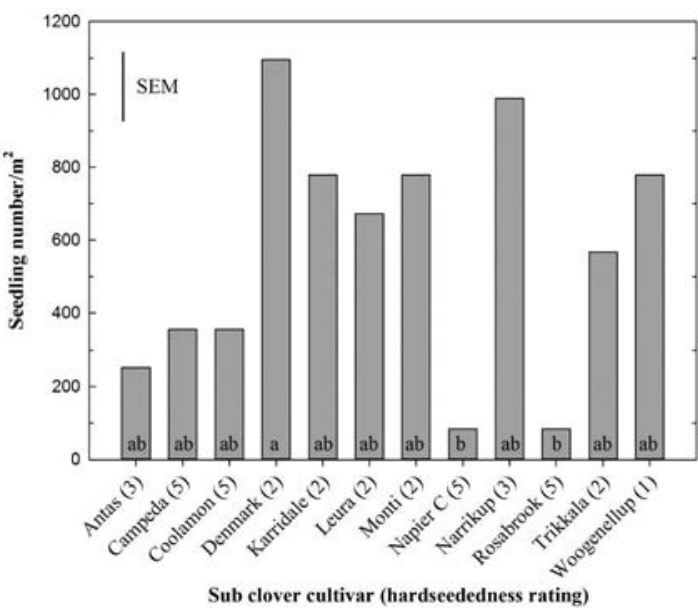

Figure 4 Subterranean clover cultivar seedling populations on 23rd May 2017 (6 weeks after emergence) at Omarama Station. Nichols et al. (2013) hardseededness rating in brackets. Means with the same letter are not different $(a=0.05)$.

\section{7 re-establishment}

In 2017 the estimated seedling populations in May for low hardseeded $(1,2)$ cultivars was 780 plants $/ \mathrm{m}^{2}$ compared with $350 / \mathrm{m}^{2}$ for medium hardseeded (3-5) cultivars $(\mathrm{P}<0.001$, Figure 4). The 'older' (pre-1999) cultivars had an estimated seedling population of 780 plants $/ \mathrm{m}^{2}$ compared with $410 / \mathrm{m}^{2}$ for the new cultivars $(\mathrm{P}=0.003)$. Cultivars with a low hardseed rating were generally also the 'older' (pre-1999) cultivars (Table 2, Figure 4).

\section{7 spring assessment}

By 20th October 2017 there was insufficient herbage for a dry matter cut due to the late start to the season and low rainfall in the spring, so groundcover was visually estimated (Figure 5). Subterranean clover groundcover differed $(\mathrm{P}=0.001)$ across cultivars being $57 \%$ for the low hardseeded and $37 \%$ for the medium hardseeded cultivars. There was higher groundcover $(\mathrm{P}=0.004)$ for the older compared with the newer cultivars (58 versus $40 \%$ ). The brachycalycinum ssp. 'Antas' had a lower $(\mathrm{P}=0.005)$ groundcover of $20 \%$ compared with the subterraneum ssp. (51\%). Other species (broadleaf weeds, grass and haresfoot) covered $34 \%$ of the plots and $16 \%$ was bare ground.

\section{8 re-establishment and autumn production}

The second re-establishment of the subterranean clover cultivars was scored on 23rd February 2018, 3 weeks after the $20 \mathrm{~mm}$ rainfall that caused germination. The subterraneum $\mathrm{ssp}$. had a higher $(\mathrm{P}=0.016)$ number of established plants at $740 / \mathrm{m}^{2}$, than the brachycalycinum

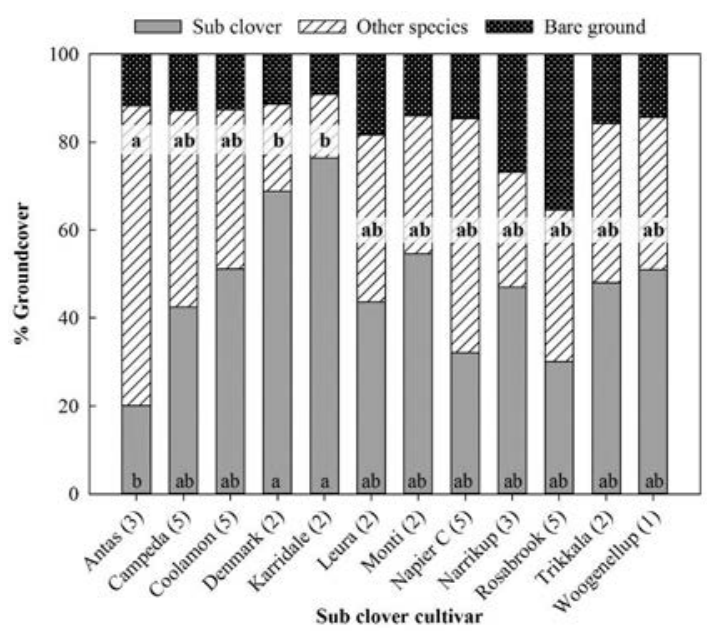

Figure 5 Visual assessment in spring of groundcover (\%) in the subterranean clover cultivar plots at Omarama Station on 20th October 2017. Nichols et al. (2013) hardseededness rating in brackets. For the subterranean clover or other species components, means with the same letter are not different $(a=0.05)$.

ssp. 'Antas' with $360 / \mathrm{m}^{2}$. The yanninicum ssp. established 600 plants $/ \mathrm{m}^{2}$. The older cultivars had 780 plants $/ \mathrm{m}^{2}$ which was higher $(\mathrm{P}=0.036)$ than the $600 /$ $\mathrm{m}^{2}$ for the newer cultivars. Balansa successfully reestablished 1200 plants $/ \mathrm{m}^{2}$ but 'Rossi' red clover had only about 1 plant/plot.

Due to early growth in 2018 , biomass was measured on 18th April 2018, about 11 weeks after the first emergence. The early-medium flowering subterranean clover cultivars yielded $1140 \mathrm{~kg} \mathrm{DM} / \mathrm{ha}$ compared with $(\mathrm{P}=0.002) 840 \mathrm{~kg} \mathrm{DM} / \mathrm{ha}$ for the late flowering cultivars (Figure 6). The brachycalycinum ssp. 'Antas', $580 \mathrm{~kg} \mathrm{DM} / \mathrm{ha}$, was less $(\mathrm{P}=0.009)$ productive than the yanninicum $\mathrm{ssp} .(1060 \mathrm{~kg} \mathrm{DM} / \mathrm{ha}$,) and the subterraneum ssp. (1020 kg DM/ha). The mean botanical composition was $70 \%$ subterranean clover, $24 \%$ other species and $6 \%$ dead material. Balansa clover produced $770 \mathrm{~kg}$ $\mathrm{DM} / \mathrm{ha}$ and resident haresfoot $360 \mathrm{~kg} \mathrm{DM} / \mathrm{ha}$.

\section{Discussion}

At Omarama the resident annual clover was haresfoot on the driest terraces but the dominant groundcover on the 'Red Flats' was hieracium. With appropriate site preparation and grazing management, subterranean clover was successfully grown and maintained with a maximum yield of $4.3 \mathrm{t} \mathrm{DM} / \mathrm{ha}$ in a favourable growing season. Balansa clover was less productive, yielding $1.3 \mathrm{t} \mathrm{DM} / \mathrm{ha}$, but was persistent. In the absence of hieracium, haresfoot was the dominant resident species and showed the potential to continue growth into the summer and produce $3.6 \mathrm{t} \mathrm{DM} /$ ha by early-December.

Across the 3 years, subterranean clover, particularly 


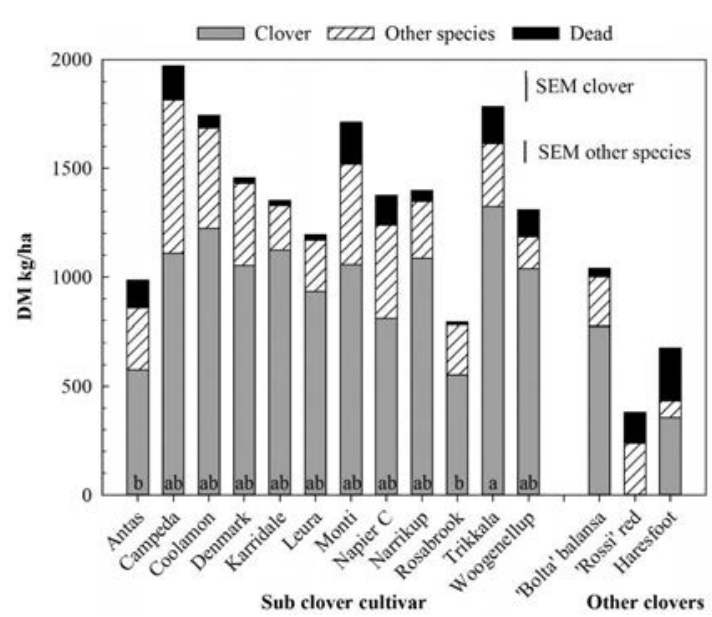

Figure 6

Dry matter yield and botanical composition from sown clovers and the resident haresfoot clover plots on 18th April 2018, 11 weeks after germination at Omarama Station. Subterranean clover cultivar means with the same letter are not different $(a=0.05)$.

the subterraneum ssp., and balansa clover persisted. Subterranean clover cultivars from the subspecies subterraneum yielded an average of $3.3 \mathrm{t} \mathrm{DM} / \mathrm{ha}$ in 2016. During the short season of 2017, the subterraneum ssp. cultivars 'Denmark' and 'Karridale' established the highest ground covers, and in 2018 'Karridale' had the highest re-establishment rate.

The brachycalycinum ssp. 'Antas' had an accumulated yield of $3 \mathrm{t} / \mathrm{ha}$ in 2016 but had the lowest ground cover in 2017, and in 2018 had the lowest reestablishment rate and autumn yield. Teixeira et al. (2018) found 'Antas' was a high seed producer (815 $\mathrm{kg} \mathrm{seed} / \mathrm{ha}$ ) but had a low burr burial rate $(40 \%)$ when grown at Lincoln, New Zealand. A lower rate of seed contact with the soil may have been a factor in the low re-establishment rates of 'Antas'. The Omarama soil had a surface $(0-75 \mathrm{~mm}) \mathrm{pH}\left(\mathrm{H}_{2} \mathrm{O}\right)$ of 5.7 (Table 1), below this the $\mathrm{pH}\left(\mathrm{H}_{2} \mathrm{O}\right)$ was 5.2 with exchangeable $\mathrm{Al}$ increasing from 0.3 to $8.0 \mathrm{mg} / \mathrm{kg}$. The acidic $\mathrm{pH}$ at depth may also have affected the persistence and productivity of 'Antas' as brachycalycinums prefer soil $\mathrm{pH}$ values greater than 6 (Ghamkhar et al. 2015).

The three yanninicum ssp. cultivars, 'Monti', 'Napier' and 'Trikkala', had low yields at Omarama when it was dry. However, 'Monti' and 'Trikkala' reestablished successfully in the wetter than normal early season of 2018 with 'Trikkala' producing the highest autumn yield. The yanninicum ssp. originates from sites prone to winter waterlogging (Nichols et al. 2013) and these results indicate that cultivars of this type are unlikely to be as productive as the subterraneum ssp. in New Zealand dryland environments. 'Rossi' red clover was as productive as balansa in 2016. However, it did not persist and was 5 to $10 \%$ of the groundcover in 2017 with few plants remaining in 2018.

In the winter of 2016, subterranean clover leaf reddening was visible in some cultivars, but was not correlated with a reduction in yield in response to winter cold. Caradus (1995) found no effect of frost down to $-16{ }^{\circ} \mathrm{C}$ on 'Tallarook' regrowth yield. This suggests the cold winter temperatures and frost at Omarama in June, July and August reduced subterranean clover cool season growth, compared with warmer locations, but did not affect the subterranean or balansa clover survival.

A longer growing season for subterranean clover at Omarama is possible when there is early emergence. A rainfall event of $20+\mathrm{mm}$ appeared to be the minimum required for emergence as occurred in February 2016 and 2018. Both events were followed by sufficient rainfall to allow up to $2 \mathrm{t}$ dry matter production before winter. Those subterranean clover cultivars most able to take advantage of this scenario had low hardseededness ratings of 1 or 2. Teixeira et al. (2018) found subterranean clover cultivars with low hardseededness ratings took advantage of early January rains in 2016. By June an average of $70 \%$ of seed from all cultivars remained ungerminated. Remaining hard seed becomes part of the seed bank that germinates in subsequent years during the temperature-dependent physiological seed softening process (Taylor 2005). Emergence at Omarama in 2018 was not affected $(\mathrm{P}=0.093)$ by hardseededness rating suggesting this factor becomes less important as the seed bank develops over time, and hard seed from previous years softens.

In spring, the erratic rainfall suggests that midflowering cultivars are more likely to reseed and persist long-term than late-flowering cultivars. However a mix of mid- and late-flowering cultivars is recommended for sowing in $500 \mathrm{~mm}$ rainfall areas (Lucas et al. 2015) to take advantage of longer growing seasons when they arise. If seed of the medium hardseeded cultivars survive in the soil over time then a mix of flowering time and hardseededness cultivars should be recommended as the soft seeded cultivars can exploit late-summer rain.

\section{On farm application}

Based on the success of resident annual clovers in similar environments (Boswell et al. 2003) recommendations have been made (Moot et al. 2012) to trial oversown balansa clover with fertiliser in this environment. For the last 5 years, a 5 ha paddock of top flowering balansa clover has yielded an average of $900 \mathrm{~kg} \mathrm{seed} / \mathrm{ha}$. This has been sown at a rate of 8 to 10 $\mathrm{kg} / \mathrm{ha}$, with $150 \mathrm{~kg} / \mathrm{ha}$ sulphur super, over Omarama Station hill-country in March/April. The farmer 
(Richard Subtil) reports balansa clover has proven to be a reliable way to refresh the legume population on the very dry, mid-altitude hill-county. Moisture levels traditionally taper off early in the spring, so the fact that balansa flowers and sets seed equally early suits the climate. The hard seed does not all germinate at the same time, so if there is an extremely dry spring, not all of the available seed is lost. In a season such as in 2016, the population of clover plants exploded and the seed bank in the soil built up. This practical, farmbased science fits the local climate and system and is a successful result from collaboration between farmers and scientists.

\section{Conclusions}

The presence of resident annual clovers (haresfoot and cluster, T. glomeratum) is a biological indicator that the environment may suit introduced commercially available annual species. In this experiment subterranean clover has been successfully established in an area with summer moisture deficits and soil fertility deficiencies. The survival of subterranean and balansa clovers was not limited by cold winters at this altitude $(<500 \mathrm{~m})$, which suggests they could be utilised more broadly across the drier zones of the Mackenzie Basin. Subterranean clover emergence and spring dry matter production were primarily influenced by rainfall that allowed early germination in February/March, and then further spring rainfall during flowering and seed set in October/November. Other factors, such as hares grazing the foliage, soil stoniness and high aluminium at depth, may affect growth and persistence.

Subterranean clover cultivars from the subterraneum ssp., such as the late-flowering 'Denmark' and 'Karridale', with low hardseededness ratings of 1 or 2 were the most productive and persistent. These cultivars re-established dominant groundcovers and produced high dry matter yields.

Balansa clover is a persistent and productive annual clover on Omarama Station and has proven to be a valuable addition to the farmers pasture system to compliment the resident annual cluster and haresfoot clovers. The poor persistence of red clover and the absence of white clover suggest perennial clovers are not suited to this environment.

\section{ACKNOWLEDGEMENTS}

Bill Gordon for site preparation and maintenance work. Lincoln University staff David Jack (seed drilling), Keith Pollock (climate data) and Malcolm Smith (workforce coordinator). Lincoln University postgraduate students Saman Berenji, Daniel Hendrie, Teresa Lewis, and Gracie Woolsey for assisting with the establishment and ongoing monitoring of the experiments. Liam Donnelly (Seed Force ${ }^{\mathrm{TM}}$ Ltd) for additional monitoring. This work was funded by the SFF Project 408090 "Sub 4 Spring", Beef + Lamb New Zealand, Luisetti Seeds and Seed Force ${ }^{\mathrm{TM}} \mathrm{Ltd}$. Mr Roland Stead provided financial assistance.

\section{REFERENCES}

Allan, B.E.; Keoghan, J.M. 1994. More persistent legumes and grasses for oversown tussock country. Proceedings of the New Zealand Grassland Association 56: 143-147.

Boswell, C.C.; Lucas, R.J.; Lonati, M.; Fletcher, A.; Moot, D.J. 2003. The ecology of four annual clovers adventive in New Zealand grasslands. Grassland Research and Practice Series 11: 175-188.

Brash, D.W.; Beecroft, F.G. 1987. Soil resources of Central Otago. Proceedings of the New Zealand Grassland Association 48: 23-30.

Caradus, J.R. 1995. Frost tolerance of Trifolium species. New Zealand Journal of Agricultural Research 38: 157-162.

CliFlo 2018. NIWA's National Climate Database on the Web. Accessed: Various dates from 1st March 2016. http://cliflo.niwa.co.nz

Dear, B.S.; Loveland, B. 1984. Herbage production and seed yield of defoliated subterranean clover swards in a cool temperate environment. Australian Journal of Experimental Agriculture and Animal Husbandry 24: 543-549.

Dodd, M.B.; Sheath, G.W.; Richardson, S. 1995. Development of subterranean clover (Trifolium subterraneum L.) genotypes for New Zealand pastures 2. Wairakei persistence evaluation. New Zealand Journal of Agricultural Research 38: 49-56.

Edmeades, D.C.; Thorrold, B.S.; Roberts, A.H.C. 2005. The diagnosis and correction of sulphur deficiency and the management of sulphur requirements in New Zealand pastures: a review. Australian Journal of Experimental Agriculture 45: 1205-1223.

Ghamkhar, K.; Nichols, P.; Erskine, W.; Snowball, R.; Murillo, M.; Appels, R.; Ryan, M.H. 2015. Hotspots and gaps in the world collection of subterranean clover (Trifolium subterraneum L.). Journal of Agricultural Science 153: 1069-1083.

Hendrie, D.L.; Moir, J.L.; Stevens, E.J.; Black, A.D.; Moot, D.J. 2018. Soil pH, exchangeable aluminium and legume yield responses to deep placed lime at Omarama Station. Journal of New Zealand Grasslands 80: 137-144.

Levy, E.B.; Gorman, L.W. 1937. Strain in subterranean clover. New Zealand Journal of Agriculture 54: 8294.

Lucas, R.J.; Mills, A.; Wright, S.; Black, A.D.; Moot, D.J. 2015. Selection of sub clover cultivars for New Zealand dryland pastures. Journal of New Zealand Grasslands 77: 203-210. 
Macfarlane, M.J.; Sheath, G.W. 1984. Clover - What types for dry hill country? Proceedings of the New Zealand Grassland Association 45: 140-150.

Macfarlane, M.J.; Sheath, G.W.; Tucker, M.A. 1990. Evaluation of clovers in dry hill country 6 . Subterranean and white clovers at Wairakei, New Zealand. New Zealand Journal of Agricultural Research 33: 557-564.

McGuire, W.S. 1985. Subterranean clover. pp. 515534. In: Clover science and technology, agronomy monograph No. 25. Ed. N.L., T. ASA-CSSA-SSSA, Madison, WI, USA.

Moir, J.; Jordan, J.; Moot, D.; Lucas, R. 2016. Phosphorous response and optimum $\mathrm{pH}$ values of twelve legumes grown in an acid upland New Zealand soil under glasshouse conditions. Journal of Soil Science and Plant Nutrition 16: 438-460.

Moir, J.L.; Moot, D.J. 2014. Medium-term soil pH and exchangeable aluminium response to liming at three high country locations. Proceedings of the New Zealand Grassland Association 76: 41-46.

Moot, D.; Black, A.; Moir, J.; Lucas, R.; Pollock, K.; Ryan-Salter, T. 2012. Forage establishment and management in the high country of New Zealand. New Zealand Merino Company. Report. Lincoln University. 45 pp.

Moot, D.; Dryland Pastures Research Team. 2016. Guide for subterranean clover identification and use in New Zealand. 1st Edition. Report No. M3779, SFF 'Sub 4 Spring' Project M408090. Lincoln University. Nichols, P.G.H.; Foster, K.J.; Piano, E.; Pecetti, L.; Kaur, P.; Ghamkhar, K.; Collins, W.J. 2013. Genetic improvement of subterranean clover (Trifolium subterraneum L.). 1. Germplasm, traits and future prospects. Crop and Pasture Science 64: 312-346.

S-MAP 2017. Manaaki Whenua Landcare Research. Accessed: 1st March 2016. https://smap. landcareresearch.co.nz

Saxby, S.H. 1956. The history of subterraneum clover in New Zealand. New Zealand Journal of Agriculture 92: 518-527.

Sheath, G.W.; Macfarlane, M.J. 1990. Evaluation of clovers in dry hill country 4. Components of subterranean clover regeneration at Whatawhata, New Zealand. New Zealand Journal of Agricultural Research 33: 541-547.

Suckling, F.E.T.; Forde, M.B.; Williams, W.M. 1983. Naturalised subterranean clover in New Zealand. New Zealand Journal of Agricultural Research 26: $35-43$.

Taylor, G.B. 2005. Hardseededness in Mediterranean annual pasture legumes in Australia: a review. Australian Journal of Agricultural Research 56: 645661.

Taylor, G.B.; Maller, R.A.; Rossiter, R.C. 1991. A model describing the influence of hardseededness on the persistence of an annual legume, in a ley farming system, in a Mediterranean-type environment. Agriculture, Ecosystems \& Environment 37: 275301.

Teixeira, C.; Lucas, R.; Lewis, T.; Moot, D. 2017. From establishment to re-establishment: a field evaluation of sub clover cultivars $I n$ : Proceedings of the 18th Australian Society of Agronomy Conference, 24-28 September 2017. Eds. O’Leary, G.J.; Armstrong, R.D.; Hafner, L., Ballarat, VIC, Australia.

Teixeira, C.S.P.; Lucas, R.J.; Moot, D.J. 2018. Seed yield and subsequent emergence pattern of subterranean clover cultivars in response to summer rain. Journal of New Zealand Grasslands 80: 91-96.

Widdup, K.; Pennell, C. 2000. Suitability of new subterranean clovers in the Canterbury region. Proceedings of the New Zealand Grassland Association 62: 161-165. 
